\title{
Validity and reliability of the Turkish version of the lymphedema symptom intensity and distress survey
}

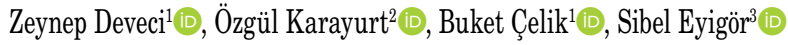 \\ ${ }^{1}$ Department of Nursing, Dokuz Eylül University, Institute of Health Sciences, Izmir, Turkey \\ ${ }^{2}$ Department of Nursing, Health Science Faculty, Izmir University of Economics, Izmir, Turkey \\ ${ }^{3}$ Department of Physical Medicine and Rehabilitation, Ege University, Faculty of Medicine, Izmir, Turkey
}

Received: March 13, 2020 Accepted: July 10, 2020 Published online: December 01, 2021

\begin{abstract}
Objectives: This study aims to adapt the Lymphedema Symptom Intensity and Distress Survey- Arm (LSIDS-Arm) into Turkish and to test its validity and reliability.

Patients and methods: Between September 2017 and July 2018, this descriptive, methodological study included a total of 186 women (mean age: $55.4 \pm 10.2$ years; range, 20 to 80 years) who were diagnosed with breast cancer-related lymphedema (BCRL) and followed in the lymphedema outpatient clinic. Data were collected using sociodemographic and clinical features form, LSIDS-Arm, and Functional Assessment of Cancer Treatment-Breast Cancer Scale+4 (FACT-B+4). After the linguistic and content validity of the scale was achieved, confirmatory factor analysis and known-groups validation were utilized to test the construct validity. Reliability of the survey was tested using the Cronbach alpha and Spearman Brown coefficient, item analysis, and parallel forms reliability.

Results: All patients completed the questionnaire. After achievement of linguistic and content validity, confirmatory factor analysis results were found to be higher than the accepted value. Known-groups validation revealed a significant difference in the mean scores for the intensity and distress scales between the patients with and without lymphedema. Cronbach alpha for the subscales ranged from 0.61 to 0.86 . Parallel forms reliability showed a moderate, significant correlation between subscales of the intensity and distress scales of the survey and the subscales of FACT-B+4.

Conclusion: The Turkish version of the survey is valid and reliable and can be used to evaluate symptoms, severity of symptoms, and distress caused by BCRL symptoms in the Turkish women.
\end{abstract}

Keywords: Breast cancer, instrument development, lymphedema, reliability validity, symptom.

Lymphedema is development of edema leading to inflammation and fibrosis as a consequence of accumulation of protein-rich fluid in the intercellular space and is a chronic disorder which may cause infection, immobility, and loss of functions. ${ }^{[1,2]}$ Breast cancer survivors have the risk of developing lymphedema in their affected arms, hands, and breast region. ${ }^{[2]}$ The incidence of breast cancer-related lymphedema (BCRL) varies from less than 5\% to more than $50 \%$ worldwide ${ }^{[2]}$ and from 6.9 to $34 \%$ in Turkey. ${ }^{[3,4]}$
Women with lymphedema experience swelling, heaviness, firmness, aching and tingling, restricted movements, numbness, pain, skin changes, redness, increased temperature, and loss of hair in the affected arm. ${ }^{[5]}$ It has been reported that women with lymphedema experience psychological symptoms such as worrying about the future, inability to fulfill their roles, and feeling of being handicapped due to restricted shoulder movements in addition to physical symptoms..$^{[4,5]}$ Besides, these women experience discomfort about their physical appearance due to

Corresponding author: Zeynep Deveci. Pamukkale Üniversitesi Sağllk Bilimleri Fakültesi, 20160 Pamukkale, Denizli, Türkiye.

e-mail: devecizeynepzd@gmail.com 
swelling and compression garments and decreased sexual drive and difficulties in sexual intercourse due to lack of spousal support. ${ }^{[6,7]}$ The quality of life (QoL) is lower in breast cancer survivors having lymphedema than in those without lymphedema. ${ }^{[8]}$

It is recommended that lymphedema should be diagnosed by combining objective methods including physical examination, volume and circumference measurements, perometry and bioimpedance with subjective methods including patients' self-reports of symptoms and QoL scales. ${ }^{[1,9,10]}$ The American Physical Therapy Association (APTA) states that self-reports of symptoms should be used to diagnose lymphedema earlier in individuals at risk of developing secondary lymphedema in the upper extremities. ${ }^{[1]}$ To date, several valid and reliable symptom scales used to diagnose BCRL and to evaluate results of treatment and interventions have been reported in the literature. Among them, the Functional Assessment of Cancer Therapy plus 4 (FACT-B+4), ${ }^{[12]}$ Norman Lymphedema Survey, ${ }^{[13]}$ Lymphedema and Breast Cancer Questionnaire, ${ }^{[14]}$ Breast Cancer and Lymphedema Symptom Experience Index, ${ }^{[15]}$ and the Lymphedema Symptom Intensity and Distress Survey-Arm (LSIDS-A) are the most widely used scales. ${ }^{[16]}$ The LSIDS-A is a valid and reliable questionnaire which was originally developed to evaluate symptoms of lymphedema including their severity and distress distributions and can be used to determine responses to treatment. ${ }^{[16]}$ Unlike other scales, it allows making an extensive psychological assessment and considering all aspects of symptoms. Another strength of the survey is that it is easy to understand the items and easy and quick to fill in. ${ }^{[16]}$

In the literature, there is no study regarding the adaptation of the LSIDS-A into other languages. However, at the time of conduct of the present study, there was no scale to determine symptom severity and distress in patients with lymphedema in Turkey. Thus, a scale which can be used to evaluate BCRL-specific symptoms was needed. Compared to development of a new scale, adapting an already available one costs less, saves time, and allows comparisons of data collected with its versions in other languages. In the present study, therefore, we aimed to adapt LSIDS-A into Turkish and to test its validity and reliability in patients with BCRL. Adaptation of LSIDS-A into Turkish would allow determining symptoms experienced by women with lymphedema including their severity and distress distributions. In addition, it would contribute to performing appropriate interventions for women with BCRL and increase the quality of care of health professionals for women with BCRL.

\section{PATIENTS AND METHODS}

This descriptive, methodological study was conducted at Ege University, Faculty of Medicine, Lymphedema outpatient clinic between September 2017 and July 2018. Prior to study, all participating women were informed about the nature of the study and a written informed consent was obtained. The study protocol was approved by the Dokuz Eylül University Ethics Committee (Date: 4.11.2016-No: 2958-GOA). Necessary permissions were also obtained from Sheila Ridner, who was one of the researchers developing LSIDS-A, through e-mail to adapt the survey into Turkish. The study was conducted in accordance with the principles of the Declaration of Helsinki.

The study population included patients with BCRL who were aged 18 years or older, had Turkish literacy, completed all cancer therapies, and voluntarily accepted to participate in the study. Exclusion criteria were as follows: having a diagnosis of metastatic cancer, diagnosis of lymphedema due to another health problem, presence of a health problem on the operated side causing motor function loss, and presence of cognitive disorders. The circumferential measurement method was used in the patients followed by the outpatient clinic. When a patient had a difference of $\geq 1.5 \mathrm{~cm}$ at any of the measuring points on her arm, she was considered to have active lymphedema, and those less than $1.5 \mathrm{~cm}$ were considered latent lymphedema. ${ }^{[17]}$ There were 154 patients with active lymphedema and 32 patients with latent lymphedema.

It is recommended that the sample size should be five to ten times as high as the number of items in the scale to perform the factor analysis of studies adapting a scale. ${ }^{[18]}$ Since the LSIDS-A is composed of 30 items, the sample of this study included 206 patients. Of these, 20 women participated in the pilot study and were not included in the analysis. Finally, a total of 186 women (mean age: $55.4 \pm 10.2$ years; range, 20 to 80 years) were analyzed. Data were collected using face-to-face interviews.

\section{Adaptation stages of LSIDS-A to Turkish}

\section{Examination of psycholinguistic features of LSIDS-A}

The survey was first translated to Turkish by three specialists experienced in translation of the documents about health sciences. Then, the best translated 
version of each item was decided by the researchers and one Turkish version of the survey was created. The language of the Turkish version was checked by a Turkish language specialist. In accordance with recommendations from this specialist, necessary revisions were made. Then, it was translated back to English by two language specialists whose native language is Turkish and who have good command of both Turkish and English languages and cultures. ${ }^{[19]}$ The back translated version was found to be similar to the original survey.

\section{Examination of psychometric features of LSIDS-A}

To achieve validity of LSIDS-A, content validity, construct validity and known-groups validity were performed. Known-groups validity was tested by examining the difference in the mean scores for LSIDS-A between the women with and without active lymphedema. To test reliability of the scale, Kuder Richardson-20 (KR-20), Cronbach alpha (a), Spearman Brown coefficients and item analysis comparing the high-low $27 \%$ mean scores and parallel forms reliability were employed. To achieve parallel forms reliability of the survey, the relationship between the scores for LSIDS-A and FACT-B+4 was examined.

\section{Assessment tools}

Data collection was performed by using a sociodemographic and clinical features form, LSIDS-A and FACT-B+4. The data were collected in a single interview with the face-to-face interview technique.

Sociodemographic and clinical features form: This form which was developed by the researchers is composed of a total of 13 questions, of which six questions are about sociodemographic features including age, education, occupation, health insurance, income and marital status, and seven questions are about clinical features including chronic diseases, treatment methods, type of surgery, sentinel lymph node biopsy, axillary lymph node dissection, body parts affected by lymphedema, and dominant hand.

LSIDS-Arm version 2.0: The survey was originally created by Ridner and Dietrich in the United States in 2015. ${ }^{[16]}$ It has two scales, symptom intensity and distress, and each scale has seven subscales as follows: soft tissue sensation, neurological sensation, function, biobehavioral, resource, sexuality, and activity. Items $1,2,8$, and 9 are loaded on soft tissue sensation, 3, 4, 5, 6, 7, 10 and 11 on neurological sensation, 12,13 on function, $14,15,16,18,19$,
20, 22, 23 and 24 on biobehavioral, 17 and 21 on resource, 25, 26 and 30 on sexuality and 27, 28 and 29 on activity. The response yes to the items is assigned one point and the response no is assigned zero. The number of the responses "Yes" is added and the total score for the survey is calculated. The lowest and highest scores to obtain from the survey are 0 and 30 , respectively. If the participant does not respond to more than five items, the total score for the survey is not calculated. Responses of participants marking "Yes" are scored based on a five-point Likert scale in the scales intensity and distress (1: too little and 5: too much). The points for Intensity and Distress are added and the mean score for the survey is obtained. The mean score for each scale is determined by calculating the mean value for responses given to the items and the total score for each item ranges from 1 to 5 . High scores for the survey show severe symptoms and distress. There is not a cut-off value for the survey. Cronbach a was 0.93 for intensity and 0.94 for distress. Cronbach a ranged from 0.74 to 0.96 for intensity and from 0.72 to 0.95 for distress. The Kuder-Richardson coefficients ranged from 0.66 to 0.92 for each subscale. It has been reported that the LSIDS-A is a valid and reliable scale to evaluate the severity of symptoms and distress caused symptoms in patients experiencing lymphedema. ${ }^{[16]}$

FACT-B+4: The scale was developed by Coster et al. ${ }^{[12]}$ in 2001 to evaluate effects of arm morbidity after breast cancer surgery on the QoL. It is composed of 42 items and six subscales: physical wellbeing, social/family wellbeing, emotional wellbeing, functional wellbeing, breast cancer, and arm. When the score for the subscale arm is excluded, the total score for the scale ranges from 0 to 148 . High total scores show a high QoL. The reason for choosing this scale for parallel form reliability is to obtain a total score from the scale and to have a sub-dimension that includes symptoms specific to BCRL. The Cronbach $\alpha$ is 0.82 for the scale and varies between 0.62 and 0.88 for its subscales. ${ }^{[12]}$ In the present study, Cronbach $a$ was found to be 0.90 for the scale and 0.88 for physical wellbeing, 0.80 for social/family, 0.87 for emotional wellbeing, 0.82 for functional wellbeing, and 0.65 for breast cancer.

\section{Statistical analysis}

Statistical analysis was performed using the IBM SPSS for Windows version 24.0 (IBM Corp., Armonk, NY, USA) and IBM SPSS AMOS version 22.0 (IBM Corp., Armonk, NY, USA) software packages. 
Descriptive data were expressed in mean \pm standard deviation (SD), median (min-max) or number and percentage, where applicable. To determine whether data about continuous variables was normally distributed, the Kolmogorov-Smirnov test was utilized. Since the data had a normal distribution, analysis of data was made with parametric tests. The relationship between the scores for LSIDS-A and FACT-B +4 was examined by Pearson correlation test. The difference in the mean scores for LSIDS-A between the women with and without was tested by the Student's t-test. The difference in the mean scores for LSIDS-A between the high-low $27 \%$ groups was evaluated with the Student's t-test. A $p$ value of $<0.05$ was considered statistically significant.

\section{RESULTS}

Of all the participating women, $49.50 \%$ were primary school graduates, $71.50 \%$ were married, $98.90 \%$ had health insurance, $58.60 \%$ were housewives, and $57 \%$ had an income equal to their expenses. Concerning treatments received by the women, $98.0 \%$ had surgery, $90.90 \%$ had chemotherapy, $84.90 \%$ had radiotherapy, $48.90 \%$ had hormonotherapy, and $12.40 \%$ had targeted therapy. Of all the women, $58.60 \%$ had mastectomy, $63.40 \%$ had sentinel lymph node biopsy, and $53.20 \%$ had axillary lymph node dissection. Lymphedema was located on the right in $51.10 \%$ of the women and on the hand and arm in $97.30 \%$ of the women (Table 1 ).

\section{Validity of LSIDS-A-TR}

\section{Content validity}

To achieve the content validity of the survey, expert opinion was obtained from two physiatrists having specialized in lymphedema, one lymphedema nurse, and two nursing academicians working on lymphedema. In accordance with suggestions from the experts, necessary changes were made. Content validity indexes (CVIs) were calculated by using the Polit and Beck technique. ${ }^{[20]}$ The CVIs for the items (I-CVI) ranged from 0.80 to 1 for the intensity scale and from 0.80 to 1 for each item of the distress scale. The CVIs for the scale (S-CVI) were 0.90 for the intensity scale and 0.96 for the distress scale.

\section{Piloting}

The LSIDS-A was piloted on 20 women who were not included in the sample. According to feedback from the piloting, item 18 about worrying about physical appearance was revised and changed into
'What other people think of your physical appearance', since it could not be understood. In addition, item 29 about decreased physical activity was changed into decreased activity in daily life and the Turkish version of LSIDS-A (LSIDS-A-TR) was obtained.

\section{Construct validity}

Since the LSIDS-A-TR is composed of two scales (i.e., symptom intensity and distress), validity and reliability analyses were made on these two scales.

To achieve construct validity of the survey, confirmatory factor analysis (CFA) and known-groups validity were utilized. The fit indexes for intensity scale were as follows: $\chi^{2} / \mathrm{df}=1.52$, root mean square error $(\mathrm{RMSE})=0.056$, root mean square residual $(\mathrm{RMR})=0.19$, comparative fit index $(\mathrm{CFI})=0.91$, goodness of fit index $(\mathrm{GFI})=0.83$, increased fit index $($ IFI $)=0.91$ and Tucker-Lewis index-TLI $=0.90$ (Table 2). The fit indexes for the distress scale were as follows: $\chi^{2} / \mathrm{df}=1.55, \mathrm{RMSA}=0.055, \mathrm{RMR}=0.27$, $\mathrm{CFI}=0.90, \quad \mathrm{GFI}=0.84, \quad \mathrm{IFI}=0.90$ and $\mathrm{TLI}=0.893$ (Figures 1, 2).

To achieve known-groups validity, the mean score for LSIDS-A-TR was compared between the women with and without lymphedema. There was a significant difference in the total scores for the intensity scale, the distress scale and their subscales between the women with and without lymphedema (Table 2).

\section{Reliability of LSIDS-A-TR}

Reliability of the LSIDS-A-TR was tested with the Cronbach $\alpha$, split half test, and item analysis of high-low group means.

The KR-20 results were 0.83 for the symptom scale of LSIDS-A-TR and ranged from 0.68 to 0.77 for subscales. The Spearman Brown coefficient in the split half test was 0.92 for the intensity scale and 0.90 for the distress scale. The Cronbach $\alpha$ ranged from 0.86 to 0.76 for the subscales of intensity and from 0.86 to 0.68 for the subscales of distress (Table 3 ). The Spearman Brown coefficients ranged from 0.89 to 0.73 for the subscales of intensity and from 0.88 to 0.65 for the subscales of distress (Table 3).

In the item analysis based on low-high group means, scores for the scale were sorted and low-high groups of 51 women were obtained. Comparisons of low-high group mean scores for the items by using the Student's t-test showed a significant difference between them (Table 4). 


\begin{tabular}{|c|c|c|c|c|}
\hline Sociodemographic and clinic & res o & artici & ints $(n=186$ & \\
\hline Variables & $\mathrm{n}$ & $\%$ & Mean \pm SD & Min-Max \\
\hline Age (year) & & & $55.3 \pm 10.2$ & 20-80 \\
\hline Duration of lymphedema (month) & & & $48.8 \pm 49.5$ & $1-204$ \\
\hline Education & & & & \\
\hline Literate & 12 & 6.5 & & \\
\hline Primary education & 92 & 49.5 & & \\
\hline High school & 29 & 15.6 & & \\
\hline University and higher level of education & 53 & 28.5 & & \\
\hline Marital status & & & & \\
\hline Married & 133 & 71.5 & & \\
\hline Single & 53 & 28.5 & & \\
\hline Health insurance & & & & \\
\hline Yes & 184 & 98.9 & & \\
\hline No & 2 & 1.1 & & \\
\hline Occupation & & & & \\
\hline Housewife & 109 & 58.6 & & \\
\hline Retired & 38 & 20.4 & & \\
\hline Government official/worker & 30 & 16.1 & & \\
\hline Worker & 9 & 4.8 & & \\
\hline Perceived income & & & & \\
\hline Higher than expenses & 20 & 10.8 & & \\
\hline Equal to expenses & 106 & 57.0 & & \\
\hline Lower than expenses & 60 & 32.3 & & \\
\hline Treatment surgery & & & & \\
\hline Yes & 183 & 98.4 & & \\
\hline No & 3 & 1.6 & & \\
\hline Chemotherapy & & & & \\
\hline Yes & 169 & 90.9 & & \\
\hline No & 17 & 9.1 & & \\
\hline Radiotherapy & & & & \\
\hline Yes & 158 & 84.9 & & \\
\hline No & 28 & 15.1 & & \\
\hline Hormonotherapy & & & & \\
\hline Yes & 91 & 48.9 & & \\
\hline No & 95 & 51.1 & & \\
\hline Target specific therapy & & & & \\
\hline Yes & 23 & 12.4 & & \\
\hline No & 163 & 87.6 & & \\
\hline Type of surgery & & & & \\
\hline Mastectomy & 109 & 58.6 & & \\
\hline Breast preserving surgery & 77 & 41.4 & & \\
\hline Sentinel lymph node biopsy & & & & \\
\hline Yes & 118 & 63.4 & & \\
\hline No & 68 & 38.6 & & \\
\hline Axillary lymph node biopsy & & & & \\
\hline Yes & 99 & 53.2 & & \\
\hline No & 87 & 46.8 & & \\
\hline Dominant hand & & & & \\
\hline Right & 160 & 86.0 & & \\
\hline Left & 26 & 14.0 & & \\
\hline Location of lymphedema $(n=154)^{*}$ & & & & \\
\hline Hand and arm & 149 & 97.3 & & \\
\hline Hand & 5 & 2.7 & & \\
\hline
\end{tabular}




\begin{tabular}{|c|c|c|c|c|c|c|c|}
\hline \multirow[b]{3}{*}{ Subscales } & \multirow[b]{3}{*}{ Active lymphedema } & \multirow{2}{*}{\multicolumn{3}{|c|}{$\begin{array}{l}\text { TABLE } 2 \\
\text { cales and subscales ir } \\
\text { Intensity }\end{array}$}} & \multirow{2}{*}{\multicolumn{3}{|c|}{ Distress }} \\
\hline & & & & & & & \\
\hline & & Mean \pm SD & $\mathrm{t}$ & $p$ & Mean \pm SD & $\mathrm{t}$ & $p$ \\
\hline \multirow{2}{*}{ Neurological sensation } & Yes & $1.1 \pm 1.0$ & \multirow{2}{*}{8.31} & \multirow{2}{*}{0.001} & $1.1 \pm 1.0$ & \multirow{2}{*}{8.10} & \multirow{2}{*}{0.001} \\
\hline & No & $0.2 \pm 0.3$ & & & $0.2 \pm 0.3$ & & \\
\hline \multirow{2}{*}{ Soft tissue sensation } & Yes & $2.1 \pm 1.3$ & \multirow{2}{*}{10.97} & \multirow{2}{*}{0.001} & $2.1 \pm 1.4$ & \multirow[t]{2}{*}{10.63} & \multirow{2}{*}{0.001} \\
\hline & No & $0.3 \pm 0.6$ & & & $0.4 \pm 0.7$ & & \\
\hline \multirow{2}{*}{ Function } & Yes & $1.4 \pm 1.6$ & \multirow{2}{*}{5.78} & \multirow{2}{*}{0.001} & $1.4 \pm 1.6$ & \multirow{2}{*}{5.57} & \multirow{2}{*}{0.001} \\
\hline & No & $0.3 \pm 0.7$ & & & $0.4 \pm 0.8$ & & \\
\hline \multirow{2}{*}{ Biobehavioral } & Yes & $1.3 \pm 0.9$ & \multirow{2}{*}{3.74} & \multirow{2}{*}{0.001} & $1.4 \pm 0.9$ & \multirow{2}{*}{3.68} & \multirow{2}{*}{0.001} \\
\hline & No & $0.7 \pm 0.7$ & & & $0.7 \pm 0.8$ & & \\
\hline \multirow{2}{*}{ Resource } & Yes & $0.6 \pm 1.2$ & \multirow{2}{*}{4.48} & \multirow{2}{*}{0.001} & $0.7 \pm 1.6$ & \multirow{2}{*}{4.20} & \multirow{2}{*}{0.001} \\
\hline & No & $0.1 \pm 0.4$ & & & $0.1 \pm 0.4$ & & \\
\hline \multirow{2}{*}{ Sexuality } & Yes & $1.0 \pm 1.5$ & \multirow{2}{*}{2.29} & \multirow{2}{*}{0.025} & $1.0 \pm 1.8$ & \multirow{2}{*}{2.85} & \multirow{2}{*}{0.005} \\
\hline & No & $0.5 \pm 1.1$ & & & $0.4 \pm 0.9$ & & \\
\hline \multirow{2}{*}{ Activity } & Yes & $1.7 \pm 1.3$ & & 0001 & $1.7 \pm 1.2$ & & \\
\hline & No & $0.8 \pm 1.2$ & 3.51 & 0.001 & & 3.64 & 0.001 \\
\hline Total score for intensity & Yes & $1.3 \pm 0.8$ & 8224 & 0001 & & & \\
\hline 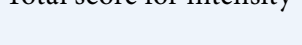 & No & $0.5 \pm 0.5$ & 0.221 & 0.001 & & & \\
\hline Total scrore for distrese & Yes & & & & $1.3 \pm 0.8$ & 8474 & 0001 \\
\hline 10tal seore ior aistiess & No & & & & $0.5 \pm 0.5$ & $0.4 / 4$ & 0.001 \\
\hline
\end{tabular}

Parallel forms for reliability analyses showed that the arm subscale of FACT-B+4 had a moderate, positive, significant correlation with the subscales of the intensity scale of LSIDS-A-TR neurological sensation $(\mathrm{r}=0.680, \mathrm{p}<0.001)$, function $(\mathrm{r}=0.710$, $\mathrm{p}<0.001)$ and soft tissue sensation $(\mathrm{r}=0.630$, $\mathrm{p}<0.001)$ and a weak, positive, significant relation with biobehavioral $(\mathrm{r}=0.375, \mathrm{p}<0.001)$ and activity

\section{TABLE 3}

Internal consistency coefficients for lymphedema intensity and distress subscales of LSIDS-A

\begin{tabular}{|c|c|c|c|c|c|}
\hline \multirow[b]{2}{*}{ Subscales } & \multirow{2}{*}{$\frac{\text { KR-20 coefficient }}{\text { Symptom }}$} & \multicolumn{2}{|c|}{ Cronbach's alpha } & \multicolumn{2}{|c|}{ Spearman Brown coefficient } \\
\hline & & $\begin{array}{c}\text { Subscales of } \\
\text { intensity }\end{array}$ & $\begin{array}{c}\text { Subscales of } \\
\text { distress }\end{array}$ & $\begin{array}{c}\text { Subscales of } \\
\text { intensity }\end{array}$ & $\begin{array}{c}\text { Subscales of } \\
\text { distress }\end{array}$ \\
\hline Neurological sensation & 0.76 & 0.85 & 0.84 & 0.79 & 0.65 \\
\hline Soft tissue sensation & 0.77 & 0.86 & 0.86 & 0.89 & 0.88 \\
\hline Function & 0.75 & 0.79 & 0.80 & 0.79 & 0.80 \\
\hline Biobehavioral & 0.70 & 0.79 & 0.68 & 0.77 & 0.83 \\
\hline Resource & 0.72 & 0.76 & 0.68 & 0.76 & 0.66 \\
\hline Sexuality & 0.68 & 0.83 & 0.71 & 0.73 & 0.65 \\
\hline Activity & 0.76 & 0.76 & 0.76 & 0.81 & 0.80 \\
\hline Symptom & 0.83 & & & & \\
\hline Intensity & & \multicolumn{2}{|c|}{0.90} & \multicolumn{2}{|c|}{0.92} \\
\hline Distress & & \multicolumn{2}{|c|}{0.89} & \multicolumn{2}{|c|}{0.90} \\
\hline
\end{tabular}




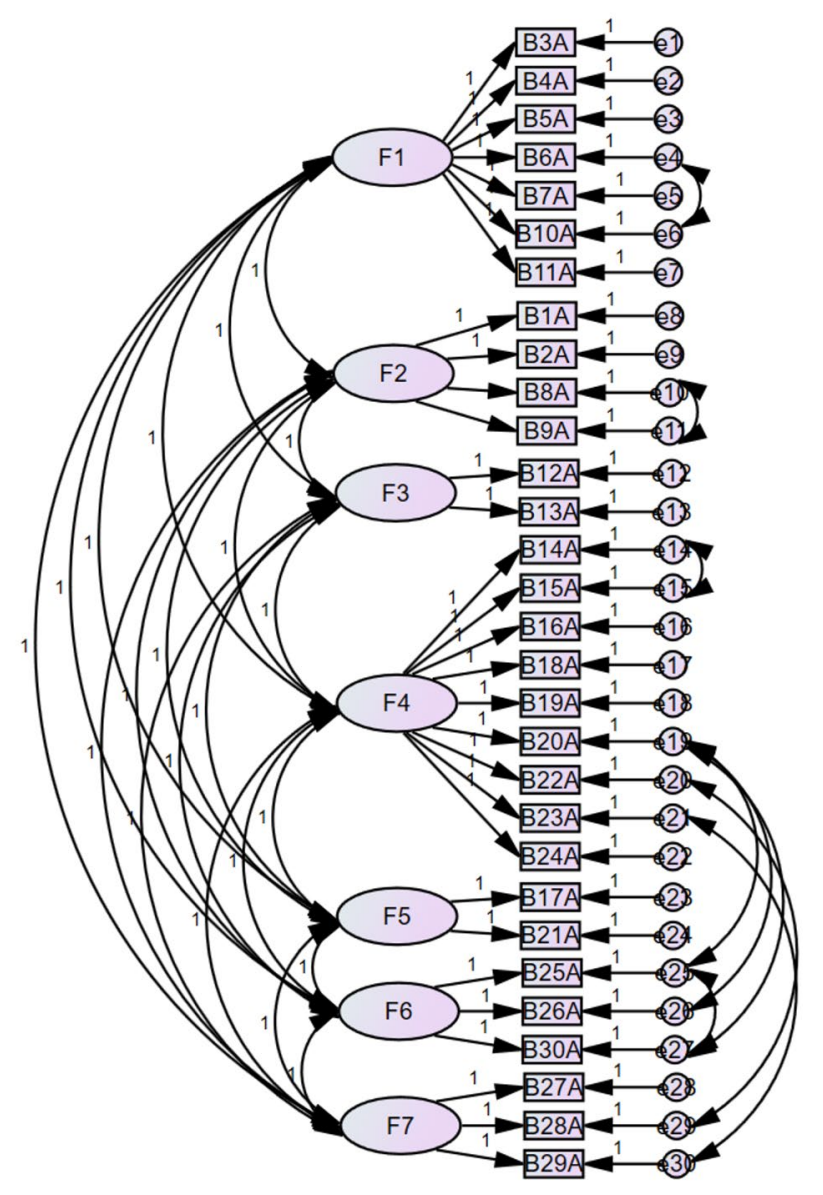

Figure 1. Intensity Scale of Lymphedema Symptom Intensity and Distress Survey-Arm-TR confirmatory factor analysis results $(\mathrm{n}=186)$.

F1: Neurological sensation; F2: Soft tissue sensation; F3: Function; F4: Biobehavioral; F5: Resource; F6: Sexuality; F7: Activity.

$(\mathrm{r}=0.382, \mathrm{p}<0.001)$. The arm subscale of FACT-B +4 had a moderate, positive, significant correlation with the subscales of the distress scale of LSIDS-A-TR neurological sensation $(\mathrm{r}=.684, \mathrm{p}<0.001)$, function $(r=0.706, p<0.001)$ and soft tissue sensation $(r=0.633$, $\mathrm{p}<0.001)$, and a weak, positive, significant correlation with biobehavioral $(\mathrm{r}=0.357, \mathrm{p}<0.001)$ and activity $(\mathrm{r}=0.380, \mathrm{p}<0.001)$. The total score for FACT-B+4 had a moderate, positive, significant correlation with the total scores for the intensity and distress scales of LSIDS-A-TR $(\mathrm{r}=0.579, \mathrm{r}=0.565, \mathrm{p}<0.001)$ (Table 5).

\section{DISCUSSION}

Patients with BCRL may experience many symptoms that affect their QoL, even in the latent period of lymphedema. ${ }^{[4-8]}$ Health-related quality of life is the primary outcome in most interventional studies of lymphedema. ${ }^{[21]}$ There are lymphedema

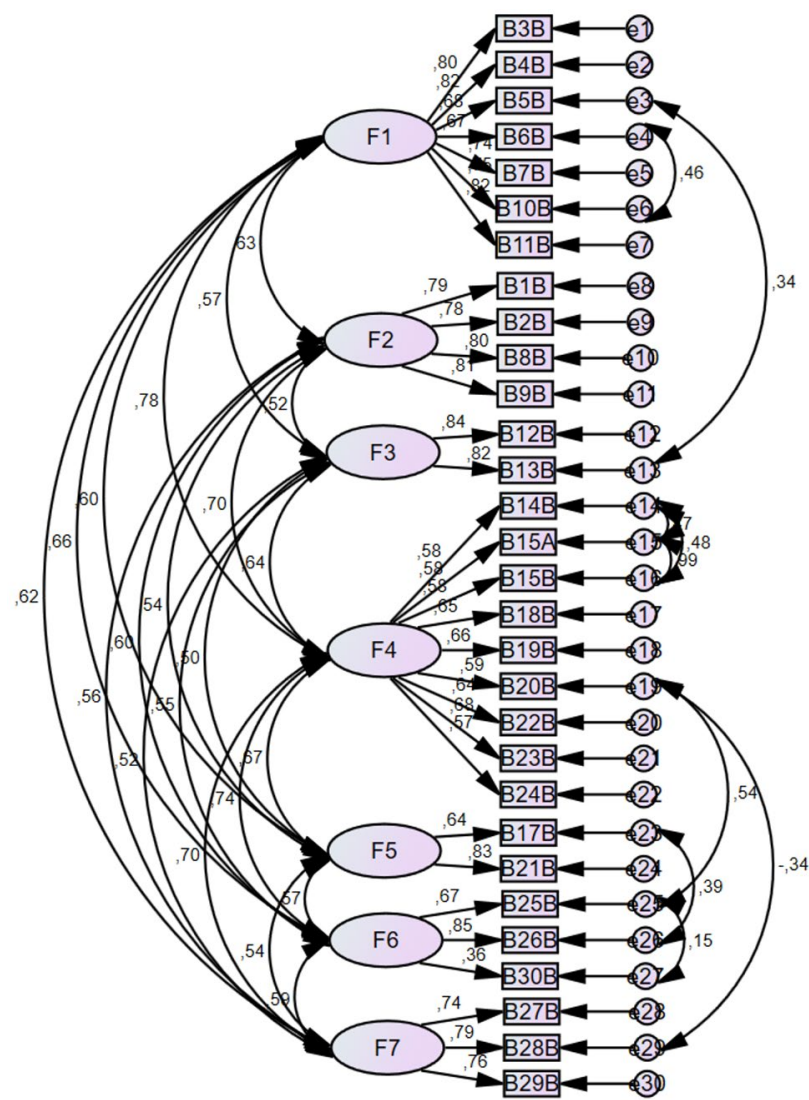

Figure 2. Distress Scale of Lymphedema Symptom Intensity and Distress Survey-Arm-TR confirmatory factor analysis results $(\mathrm{n}=186)$

F1: Neurological sensation; F2: Soft tissue sensation; F3: Function; F4: Biobehavioral; F5: Resource; F6: Sexuality; F7: Activity.

scales for measuring the BRCL patients' QoL in Turkey. ${ }^{[22-25]}$ It has been shown in interventional studies that not only measurement scores and the QoL $^{[26-28]}$ but also symptoms ${ }^{[27,28]}$ in patients with BCRL are affected. To date, there has been no valid and reliable scale to measure lymphedemarelated symptoms and the severity and intensity of symptoms. In the present study, LSIDS-A-TR was tested for validity and reliability in Turkish patients with BCRL.

\section{Validity of LSIDS-A-TR}

To examine construct validity of LSIDS-A-TR, CFA was made to test whether the items accurately measured lymphedema symptoms, the symptom intensity and distress caused by the symptoms and to what extent the subscales could explain the construct of the survey. ${ }^{[29]}$ The CFA is used to determine whether a prespecified model functions in a new sample. ${ }^{[30]}$ Therefore, in the current study, CFA was performed to 


\section{TABLE 4}

Results of item analysis based on differences between high-low group means for lymphedema intensity and distress subscales of LSIDS-A

\begin{tabular}{|c|c|c|c|c|}
\hline \multirow[b]{2}{*}{ Items } & \multicolumn{2}{|c|}{ Intensity subscale } & \multicolumn{2}{|c|}{ Distress subscale } \\
\hline & $\mathrm{t}$ & $p$ & $\mathrm{t}$ & $p$ \\
\hline 1 & 11.613 & 0.001 & -11.416 & 0.001 \\
\hline 2 & 10.780 & 0.001 & -12.883 & 0.001 \\
\hline 3 & 5.742 & 0.001 & -5.764 & 0.001 \\
\hline 4 & 5.507 & 0.001 & -5.192 & 0.001 \\
\hline 5 & 8.080 & 0.001 & -8.880 & 0.001 \\
\hline 6 & 6.312 & 0.001 & -5.955 & 0.001 \\
\hline 7 & 6.976 & 0.001 & -7.569 & 0.001 \\
\hline 8 & 12.953 & 0.001 & -12.706 & 0.001 \\
\hline 9 & 10.949 & 0.001 & -10.946 & 0.001 \\
\hline 10 & 7.841 & 0.001 & -6.306 & 0.001 \\
\hline 11 & 4.697 & 0.001 & -4.902 & 0.001 \\
\hline 12 & 8.216 & 0.001 & -9.912 & 0.001 \\
\hline 13 & 7.571 & 0.001 & -8.202 & 0.001 \\
\hline 14 & 8.050 & 0.001 & -10.102 & 0.001 \\
\hline 15 & 5.839 & 0.001 & -5.811 & 0.001 \\
\hline 16 & 4.745 & 0.001 & -5.232 & 0.001 \\
\hline 17 & 3.820 & 0.001 & -2.738 & 0.009 \\
\hline 18 & 6.520 & 0.001 & -6.380 & 0.001 \\
\hline 19 & 5.567 & 0.001 & -5.796 & 0.001 \\
\hline 20 & 5.705 & 0.001 & -5.473 & 0.001 \\
\hline 21 & 3.185 & 0.002 & -3.419 & 0.001 \\
\hline 22 & 10.431 & 0.001 & -10.535 & 0.001 \\
\hline 23 & 9.589 & 0.001 & -11.638 & 0.001 \\
\hline 24 & 6.256 & 0.001 & -6.314 & 0.001 \\
\hline 25 & 6.356 & 0.001 & -4.730 & 0.001 \\
\hline 26 & 3.448 & 0.001 & -2.876 & 0.005 \\
\hline 27 & 8.341 & 0.001 & -8.021 & 0.001 \\
\hline 28 & 8.763 & 0.001 & -8.554 & 0.001 \\
\hline 29 & 11.810 & 0.001 & -13.118 & 0.001 \\
\hline 30 & 6.414 & 0.001 & -2.752 & 0.008 \\
\hline
\end{tabular}

examine whether LSIDS-A is appropriate in Turkish culture. Many fit indexes are available and new fit indexes are being developed for CFA. However, it has been suggested that fit indexes from different groups should be utilized to perform CFA. ${ }^{[31]}$ Maruyama $^{[32]}$ classified them into absolute fit indexes, relative fit indexes, parsimony fit indexes, and noncentrality indexes. Therefore, in the current study, absolute fit indexes GFI and RMR, relative fit indexes, IFI and TLI, and noncentrality indexes, RMSEA and CFI, were used. The fit indexes were lower than $\chi^{2} / \mathrm{df}$, CFI, IFI and TLI were higher than 0.9 and RMSEA ranged from 0.05 to 0.10 for the intensity and distress scales of LSIDS-A-TR. This finding indicates that the survey has an acceptable fit. The finding that five indexes for LSIDS-A-TR were acceptable confirmed the seven-factor structure of the survey.

In addition to CFA, known-groups comparisons were utilized to test construct validity. In known-groups comparisons, the presence of a difference between scores for a scale administered to two different groups shows that the scale has construct validity. ${ }^{[33]}$ Therefore, in the present study, the women with active lymphedema were compared with those having latent lymphedema. The finding that the women with active lymphedema had higher mean scores for the intensity and distress scales of LSIDS-A-TR showed that the survey had a good construct validity.

\section{Reliability}

The fact that a scale is reliable indicates that it can consistently perform measurements. The KR-20 coefficient, based on consistency between items of a scale, is used to measure reliability of the items which can be scored as zero and one. It is expected that KR-20 coefficient should be over $0.70 . .^{[34]}$ The finding that KR-20 coefficient for the first part of LSIDS-A-TR questioning presence of lymphedema symptoms was over 0.70 shows that items of the survey are reliable. Consistent with this finding, KR-20 coefficient for the original scale was $0.88 .{ }^{[16]}$ One of the methods used to determine whether a scale can consistently measure a given conceptual framework in a single measurement is an internal consistency reliability coefficient Cronbach $\alpha$. It is utilized to determine whether questions in a scale represent a homogenous structure. ${ }^{[35]}$ It is recommended that Cronbach a should be higher than $0.60 .{ }^{[33]}$ It ranged from 0.76 to 0.86 for the intensity scale of LSIDS-A-TR. Consistent with this finding, Cronbach a varied between 0.74 and 0.96 for the subscales of the intensity scale of the original survey. ${ }^{[16]}$ It ranged from 0.61 to 0.86 for the distress scale of LSIDS-A. Since the resource subscale involves two questions, its Cronbach $\alpha$ of 0.61 can be acceptable. ${ }^{[36]}$ The Cronbach $\alpha$ for the distress scale of the original survey ranges from 0.72 to $0.95 .^{[16]}$ Results of the internal reliability analyses in the present study showed that the items of LSIDS-A-TR were related 


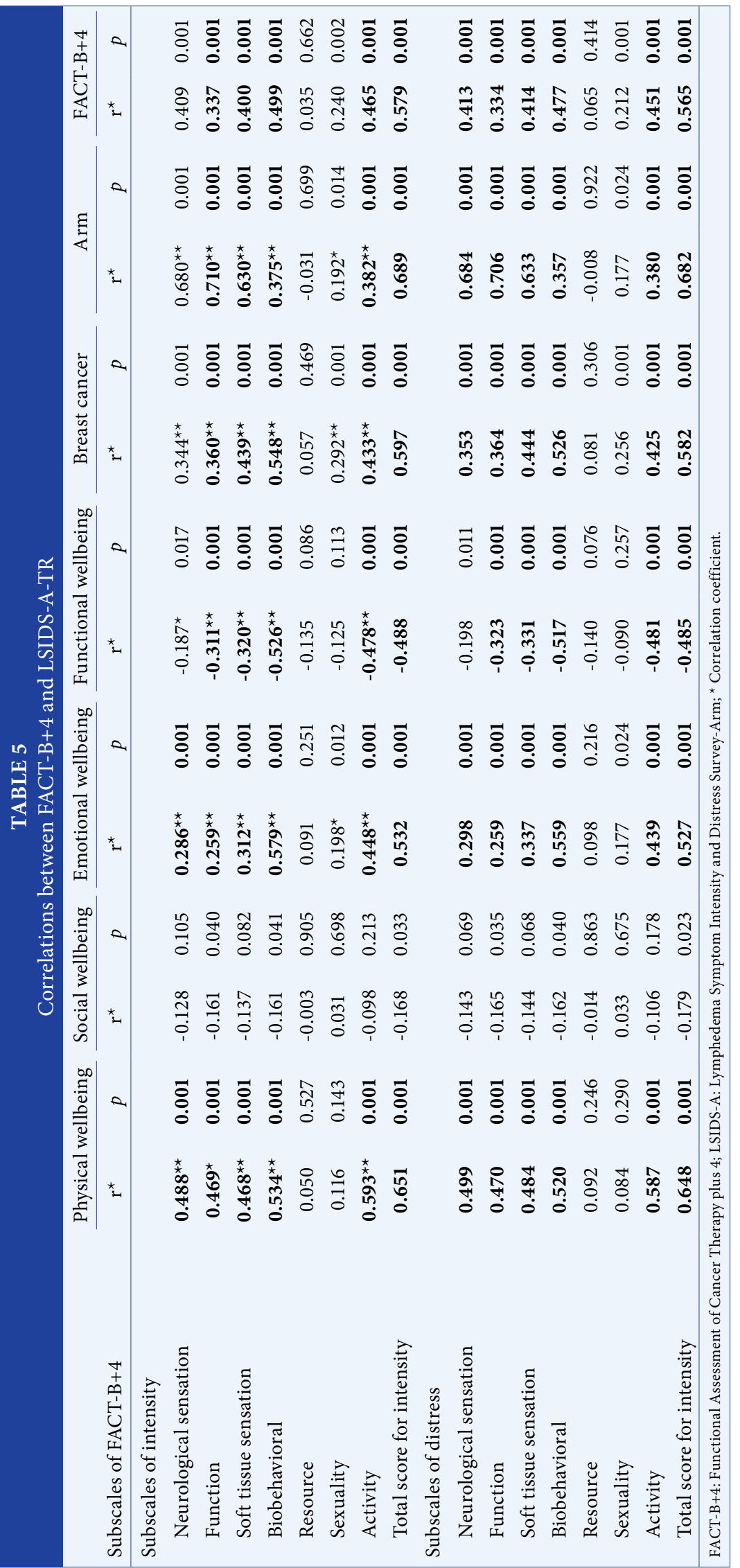


to each other, homogenous, predictive of the same concept and reliable.

Another method used to measure internal consistency of a scale is split half test. The Spearman Brown coefficient of over 0.70 in the split half test indicates presence of internal consistency of that scale. ${ }^{[37]}$ A method utilized to test reliability is item analysis. When scores for a scale put in order from the highest to the lowest, a comparison between mean scores for each item of $27 \%$ of the groups at both ends refers to item analysis. ${ }^{[18]}$ These analyses reveal whether all items of a scale have significantly discriminating power. Item analyses show the ability of items of a scale to represent subscales of that scale and their contributions to the scale. ${ }^{[38]}$ In the item analysis technique, based on the difference between low-high 27\% means (internal consistency criterion), presence of a significant difference for all items of LSIDS-A-TR showed that the internal reliability of the survey was achieved. ${ }^{[38]}$

Parallel form reliability is another test utilized to evaluate the reliability of the scale. ${ }^{[38]}$ In this method, reliability is achieved by finding a relation between forms directed toward achieving the same goal. Since there is no valid and reliable parallel form measuring lymphedema symptom and distress in the Turkish population at the time of the study conduct, one of the forms used to develop the original scale FACT-B+4 was preferred, since it has a subscale about lymphedema. There was a moderate, positive, significant correlation between the mean score for FACT-B +4 and the mean scores for the intensity and distress scales of LSIDS-A-TR. The arm subscale of FACT-B +4 also had a moderate and significant correlation with the subscales of the intensity and distress scales of LSIDS-A-TR neurological sensation, function, soft tissue sensation and activity. The presence of a moderate and significant correlation between FACT-B+4 and LSIDS-A-TR showed that parallel form reliability of the survey was achieved. In the correlation of the original scale with the FACT-B +4 , strong correlations were obtained between the FACT-B +4 and the subscales neurological sensation, function, soft tissue sensation, consistent with the present study. ${ }^{[16]}$

Nonetheless, there are some limitations to the present study. One of them is that there was no scale adapted to Turkish to test all subscales of LSIDS-A-TR to achieve parallel form reliability of the survey. Another limitation is that the test-retest reliability method was not used in this study.
In conclusion, women with BCRL experience physical, social, and psychological problems and many other symptoms, in addition to lymphedema. The LSIDS-A-TR is valid and reliable in the Turkish patients with BRCL. The LSIDS-A-TR can be utilized by clinicians and researchers to make a better and comprehensive evaluation of BCRL. In addition, when it is used to evaluate outcomes of interventions performed by health professionals such as nurses, physiotherapists and physicians, it can contribute to improvement of the quality of care for patients and the QoL of patients.

\section{Declaration of conflicting interests}

The authors declared no conflicts of interest with respect to the authorship and/or publication of this article.

Funding

The authors received no financial support for the research and/or authorship of this article.

\section{REFERENCES}

1. Shaitelman SF, Cromwell KD, Rasmussen JC, Stout NL, Armer JM, Lasinski BB, et al. Recent progress in the treatment and prevention of cancer-related lymphedema. CA Cancer J Clin 2015;65:55-81.

2. Gillespie TC, Sayegh HE, Brunelle CL, Daniell KM, Taghian AG. Breast cancer-related lymphedema: risk factors, precautionary measures, and treatments. Gland Surg 2018;7:379-403.

3. Soyder A, Taştaban E, Özbaş S, Boylu Ş, Özgün H. Frequency of early-stage lymphedema and risk factors in postoperative patients with breast cancer. J Breast Health 2014;10:92-7.

4. Şimşir Atalay N, Taflan Selçuk S, Ercidoğan Ö, Akkaya N, Sarsan A, Yaren A, et al. Meme cerrahisi ve aksiller diseksiyon uygulanan meme kanserli hastalarda üst ekstremite problemlerinin sıklığı ve yaşam kalitesine etkisi. Türk Fiz Tip Rehab Derg 2011;57:186-92.

5. Fu MR, Axelrod D, Cleland CM, Qiu Z, Guth AA, Kleinman R, et al. Symptom report in detecting breast cancer-related lymphedema. Breast Cancer (Dove Med Press) 2015;7:345-52.

6. Winch CJ, Sherman KA, Koelmeyer LA, Smith KM, Mackie $\mathrm{H}$, Boyages J. Sexual concerns of women diagnosed with breast cancer-related lymphedema. Support Care Cancer 2015;23:3481-91.

7. Radina ME, Fu MR, Horstman L, Kang Y. Breast cancerrelated lymphedema and sexual experiences: a mixed-method comparison study. Psychooncology 2015;24:1655-62.

8. Cornelissen AJM, Kool M, Keuter XHA, Heuts EM, Piatkowski de Grzymala AA, van der Hulst RRWJ, et al. Quality of life questionnaires in breast cancer-related lymphedema patients: review of the literature. Lymphat Res Biol 2018;16:134-9.

9. International Society of Lymphology. The diagnosis and treatment of peripheral lymphedema: 2013 Consensus 
Document of the International Society of Lymphology. Lymphology 2013;46:1-11.

10. Bakar Y, Berdici B, Sahin N, Pala OO. Lymphedema after breast cancer and its treatment. Eur J Breast Health 2014;10:6-14.

11. Levenhagen K, Davies C, Perdomo M, Ryans K, Gilchrist L. Diagnosis of upper quadrant lymphedema secondary to cancer: Clinical Practice Guideline From the Oncology Section of the American Physical Therapy Association. Phys Ther 2017;97:729-45.

12. Coster S, Poole K, Fallowfield LJ. The validation of a quality of life scale to assess the impact of arm morbidity in breast cancer patients post-operatively. Breast Cancer Res Treat 2001;68:273-82.

13. Norman SA, Miller LT, Erikson HB, Norman MF, McCorkle R. Development and validation of a telephone questionnaire to characterize lymphedema in women treated for breast cancer. Phys Ther 2001;81:1192-205.

14. Bulley C, Coutts F, Blyth C, Jack W, Chetty U, Barber M, et al. A Morbidity Screening Tool for identifying fatigue, pain, upper limb dysfunction and lymphedema after breast cancer treatment: a validity study. Eur J Oncol Nurs 2014;18:218-27.

15. MR Fu, CM Cleland, Y Kang. Measuring lymphedema symptom burdens: a psychometric study. Paper presented at the Multinational Association of Supportive Care in Cancer's Annual Meeting (MASCC/ISOO), June 28-30, 2012. New York: 2012.

16. Ridner SH, Dietrich MS. Development and validation of the Lymphedema Symptom and Intensity Survey-Arm. Support Care Cancer 2015;23:3103-12.

17. Moseley A, Piller N. The assessment and care of the patient with secondary limb lymphoedema. Aust Nurs J 2002;10:suppl1-4.

18. Tavşancıl E. Tutumların ölçülmesi ve SPSS ile veri analizi. 4. Baskı. Ankara: Nobel Yayın Dağıtım; 2006.

19. Deniz Z. The Adaptation of Psychological Scales. Ankara University Journal of Faculty of Educational Sciences (JFES) 2007;40:1-16.

20. Polit DF, Beck CT. The content validity index: are you sure you know what's being reported? Critique and recommendations. Res Nurs Health 2006;29:489-97.

21. Ridner S, Deng J, Rhoten BA. Adherence and quality of life. In: Lee BB, Rockson SG, Bergan J, editors. Lymphedema: A Concise Compendium of Theory and Practice. 2nd ed. Berlin: Springer; 2018. p. 497.

22. Kayali Vatansever A, Yavuzşen T, Karadibak D. The reliability and validity of quality of life questionnaire upper limb lymphedema (ULL-27) Turkish patient with breast cancer related lymphedema. Front Oncol 2020;10:455.
23. Borman P, Yaman A, Denizli M, Karahan S, Özdemir O. The reliability and validity of Lymphedema Quality of Life Questionnaire-Arm in Turkish patients with upper limb lymphedema related with breast cancer. Turk J Phys Med Rehabil 2018;64:205-12.

24. Karayurt Ö, Deveci Z, Eyigör S, Özgür İnbat M. Adaptation of quality of life measure for limb lymphedema-arm in Turkish women with breast cancer-related lymphedema. Cancer Nurs 2021;44:45-52.

25. BakarY, Tuğral A, ÖzdemirÖ, Duygu E, Üyetürk Ü.Translation and validation of the Turkish version of lymphedema quality of life tool (LYMQOL) in patients with breast cancer related lymphedema. Eur J Breast Health 2017;13:123-8.

26. Kasawara KT, Mapa JMR, Ferreira V, Added MAN, Shiwa SR, Carvas N Jr, et al. Effects of Kinesio Taping on breast cancer-related lymphedema: A meta-analysis in clinical trials. Physiother Theory Pract 2018;34:337-45.

27. Ezzo J, Manheimer E, McNeely ML, Howell DM, Weiss $\mathrm{R}$, Johansson KI, et al. Manual lymphatic drainage for lymphedema following breast cancer treatment. Cochrane Database Syst Rev 2015;5:CD003475.

28. Baxter GD, Liu L, Petrich S, Gisselman AS, Chapple C, Anders JJ, et al. Low level laser therapy (Photobiomodulation therapy) for breast cancer-related lymphedema: a systematic review. BMC Cancer 2017;17:833.

29. Karakoç FY, Dönmez L. Ölçek geliştirme çalışmalarında temel ilkeler. Tıp Eğitimi Dünyası 2014;40:39-49.

30. Aytaç M, Öngen B. Doğrulayıcı faktör analizi ile yeni çevresel paradigma ölçeğinin yapı geçerliliğinin incelenmesi. İstatistikçiler Dergisi: İstatistik ve Aktüerya 2012;5:14-22.

31. Shevlin M, Miles JNV, Lewis CA. Reassessing the fit of the confirmatory factor analysis of the multidimensional students life satisfaction scale: comments on 'confirmatory factor analysis of the multidimensional Students' Life Satisfaction Scale'. Personality and Individual Differences 2000;28:181-5.

32. Maruyama GM. Logic of alternative models and significance tests. In: Basics of Structural Equation Modeling. [online] New York: SAGE Publications Inc.; 1998.

33. Şencan H. Sosyal ve davranışsal ölçümlerde geçerlilik ve güvenilirlik. 1. Baskı. Ankara: Seçkin Yayıncılık; 2005.

34. Özen Y, Gülaçti F, Kandemir M. Eğitim bilimleri araştırmalarında geçerlik ve güvenirlik sorunsalı. Erzincan Eğitim Fakültesi Dergisi 2006;8:69-89.

35. Tavakol M, Dennick R. Making sense of Cronbach's alpha. Int J Med Educ 2011;2:53-55.

36. Kılıç S. Cronbach's alpha reliability coefficient. Journal of Mood Disorders 2016;6:47-8.

37. Büyüköztürk Ş. Sosyal bilimler için veri analizi el kitabı. 16. Baskı. Ankara: Pegem Akademi Yayınları; 2010.

38. Gürbüz S, Şahin F. Sosyal bilimlerde araştırma. 4. Baskı. Ankara: Seçkin Yayıncılık; 2017. 